\title{
Adenovirus/Cytomegalovirus/Epstein-Barr Virus-specific Allogeneic Cytotoxic T Lymphocytes
}

National Cancer Institute

\section{Source}

National Cancer Institute. Adenovirus/Cytomegalovirus/Epstein-Barr Virus-specific

Allogeneic Cytotoxic T Lymphocytes. NCI Thesaurus. Code C100102.

Allogeneic tri-viral specific, adenovirus, cytomegalovirus and Epstein-Barr virus (Adv, CMV and EBV or ACE), cytotoxic T-lymphocytes (CT LS) with potential antiviral activity. Donorderived T-cells were exposed to dendritic cells nucelofected with DNA plasmids encoding Hexon and Penton (Adv), pp65 and IE1 (CMV), and LMP2, EBNA1 and BZLF1 (EBV), all are critical proteins for the proliferation of these viruses, and subsequently maintained in the presence of interleukins 4 and 7 with a novel culture device to expand and sustain the repertoire of CT Ls. After an allogeneic hematopoietic stem cell transplant (HSCT), infusion of these CT Ls primed towards Adv, CMV and EBV may prevent viral infection by these pathogens. 